OPEN ACCESS

Edited by:

Antiopi Varelias,

The University of Queensland,

Australia

Reviewed by:

Govindarajan Thangavelu, University of Minnesota Twin Cities,

United States

Federico Simonetta,

Geneva University Hospitals (HUG),

Switzerland

Kate Markey,

Memorial Sloan Kettering Cancer

Center, United States

*Correspondence:

Defu Zeng

dzeng@coh.org

Specialty section:

This article was submitted to Alloimmunity and Transplantation,

a section of the journal

Frontiers in Immunology

Received: 27 April 2021

Accepted: 13 August 2021 Published: 03 September 2021

Citation:

Song Q, Kong X, Martin PJ and Zeng D (2021) Murine Models Provide New Insights Into Pathogenesis of Chronic Graft-Versus-Host Disease in Humans.

Front. Immunol. 12:700857. doi: 10.3389/fimmu.2021.700857

\section{Murine Models Provide New Insights Into Pathogenesis of Chronic Graft- Versus-Host Disease in Humans}

\author{
Qingxiao Song ${ }^{1,2,3}$, Xiaohui Kong ${ }^{1,2}$, Paul J. Martin ${ }^{4,5}$ and Defu Zeng ${ }^{1,2 *}$ \\ ${ }^{1}$ Riggs Institute, The Beckman Research Institute, City of Hope National Medical Center, Duarte, CA, United States, 2 Hematologic \\ Malignancies and Stem Cell Transplantation Institute, City of Hope National Medical Center, Duarte, CA, United States, ${ }^{3}$ Fujian \\ Medical University Center of Translational Hematology, Fuilan Medical University Union Hospital, Fuzhou, China, ${ }^{4}$ Division of Clinical \\ Research, Fred Hutchinson Cancer Research Center, Seattle, WA, United States, ${ }^{5}$ Department of Medicine, University of \\ Washington, Seattle, WA, United States
}

Allogeneic hematopoietic cell transplantation (allo-HCT) is a curative therapy for hematologic malignancies, but its success is complicated by graft-versus-host disease (GVHD). GVHD can be divided into acute and chronic types. Acute GVHD represents an acute alloimmune inflammatory response initiated by donor $T$ cells that recognize recipient alloantigens. Chronic GVHD has a more complex pathophysiology involving donorderived $T$ cells that recognize recipient-specific antigens, donor-specific antigens, and antigens shared by the recipient and donor. Antibodies produced by donor B cells contribute to the pathogenesis of chronic GVHD but not acute GVHD. Acute GVHD can often be effectively controlled by treatment with corticosteroids or other immunosuppressant for a period of weeks, but successful control of chronic GVHD requires much longer treatment. Therefore, chronic GVHD remains the major cause of long-term morbidity and mortality after allo-HCT. Murine models of allo-HCT have made great contributions to our understanding pathogenesis of acute and chronic GVHD. In this review, we summarize new mechanistic findings from murine models of chronic GVHD, and we discuss the relevance of these insights to chronic GVHD pathogenesis in humans and their potential impact on clinical prevention and treatment.

Keywords: hematopoietic cell transplantation, chronic graft-versus-host disease, mouse models, tissue resident memory T cell, B cell

\section{INTRODUCTION}

Allogeneic hematopoietic cell transplantation (allo-HCT) offers a way to eliminate residual malignant cells and prevent relapse by taking advantage of the graft-versus-leukemia/lymphoma (GVL) activity of alloreactive donor T cells (1-6). However, the same alloreactive T cells also mediate graft-versus-host disease (GVHD) (7-9). Acute GVHD is an acute alloimmune inflammatory response characterized by infiltration of donor $\mathrm{T}$ cells that cause apoptosis and necroptosis of epithelial cells in GVHD target tissues (10-12). Chronic GVHD is an autoimmune-like chronic inflammation variably characterized with lymphopenia, IgG autoantibodies in the serum (13), moderate donor cell infiltration, and fibrosis in certain target tissues (14). Chronic GVHD often occurs as a sequel of acute GVHD, although chronic 
GVHD can occur in the absence of overt acute GVHD (15). In humans, acute and chronic GVHD can both involve the skin, liver, and gut, whereas prototypical target organs affected by chronic GVHD include salivary and lacrimal glands, oral mucosa, subcutaneous connective tissue and adipose tissue, lung, genital tract, and esophagus (15-18). Clinical manifestations of chronic GVHD typically begin between 2 and 12 months after allo-HCT $(15,19)$. In one retrospective study, $75 \%$ of the patients diagnosed with chronic GVHD had prior acute GVHD, and in $10 \%$ of the patients, acute GVHD evolved directly into chronic GVHD (20).

Studies of GVHD pathogenesis in humans are limited by the inaccessibility of target organ tissues other than the skin. Therefore, preclinical animal models represent important tools for elucidating the pathogenic processes leading to acute and chronic GVHD (21, 22). Murine models of allo-HCT have become the most important animal models for the GVHD mechanistic pathogenic studies, owing to the availability of genetically modified strains $(21,22)$, although work with canine and nonhuman primate models has produced important contributions $(23,24)$. Murine models of alloHCT have demonstrated the role of recipient mismatching for major and minor histocompatibility antigens in triggering acute GVHD. These models have also elucidated the role of T-cell subsets and cytokines in acute GVHD pathogenesis (25-36). As one example, observations from murine models that NKT cells specific for nonpolymorphic CD1d suppressed acute GVHD (37) and preservation of NKT cells by conditioning regimens consisting of total lymphoid irradiation (TLI) and antithymocytes cell globulin (ATG) prevented GVHD while preserving GVL activity $(38,39)$ have been successfully translated into clinical application in humans $(40,41)$. Similarly, observations from murine models that removal of naïve $\mathrm{T}$ cells can ameliorate GVHD while preserving GVL activity $(42,43)$ have also been successfully translated into clinical application in humans (44).

Modeling chronic GVHD appeared to be more complicated, but murine models of chronic GVHD have evolved and improved during the past three decades. It was initially thought that murine models of autoimmune-like chronic GVHD required specific donor-recipient combinations that differ from those used to study acute $\operatorname{GVHD}(21,22,45)$. In this review, we will describe how we have used identical allogeneic donor and recipient strain combinations to induce acute GVHD mediated by alloreactive T cells and to induce autoimmune-like chronic GVHD. In these models, acute and chronic GVHD can occur sequentially in murine recipients (46), similar to what most often occurs in humans (15). These murine models also reflect the characteristic features of autoimmune-like chronic GVHD in humans (46). We will also summarize new insights into chronic GVHD pathogenesis through the murine models.

\section{A MURINE MODEL CAN REFLECT CHARACTERISTIC FEATURES OF CHRONIC GVHD IN PATIENTS}

We recently found that induction of acute and chronic GVHD does not require different donor and host combination (46). With the commonly used acute GVHD model of C57BL/6 donor to MHCmismatched $\mathrm{BALB} / \mathrm{c}$ recipient, acute $\mathrm{GVHD}$ recipients develop into chronic GVHD as long as they survive for up to 60 days after alloHCT (46). The induction of both acute and chronic GVHD can be achieved by adjusting donor T-cell numbers in the graft, and chronic GVHD in the absence of acute GVHD can be induced by injection of purified donor $\mathrm{CD}^{+} \mathrm{T}$ cells alone with T-cell-depleted bone marrow cells (46). Recipients with chronic GVHD induced by whole splenic $\mathrm{T}$ cells or by sorted donor $\mathrm{CD} 8^{+} \mathrm{T}$ cells both have lymphopenia, damage in the thymus, serum autoantibodies, and damage in small intestine, liver, lung, skin, and salivary and lacrimal glands, together with collagen deposition and fibrosis in target organ tissues $(46,47)$. The recipients clearly showed lymphocytic bronchiolitis and interstitial collagen deposition in the lung (46, 47), although bronchial obstruction (BO) observed in a murine model conditioned with TBI plus cyclophosphamide (CY) (48) was not observed in our models. BO in murine model of chronic GVHD may require special conditioning. In addition, as summarized in Table 1, chronic GVHD can be induced with low-dose splenic T cells in other MHC-mismatched or MHC-matched donor-recipient combinations, including MHC-mismatched C57BL/6 (H-2 $\left.{ }^{\mathrm{b}}\right)$ donor to $\mathrm{B} 10 \mathrm{BR}\left(\mathrm{H}-2^{\mathrm{k}}\right)$ recipient and $\mathrm{MHC}$-matched $\mathrm{LP} / \mathrm{J}\left(\mathrm{H}-2^{\mathrm{b}}\right)$ donor to $\mathrm{C} 57 \mathrm{BL} / 6\left(\mathrm{H}-2^{\mathrm{b}}\right)$ recipient and DBA/2 $\left(\mathrm{H}-2^{\mathrm{d}}\right)$ or B10D2 $\left(\mathrm{H}-2^{\mathrm{d}}\right)$ donor to $\mathrm{BALB} / \mathrm{c}\left(\mathrm{H}-2^{\mathrm{d}}\right)$ recipient models $(46,49-55)$. Chronic GVHD with little acute GVHD can also be induced by naïve $\mathrm{CD} 8^{+} \mathrm{T}$ cells from C3H.SW (H-2D $\left.{ }^{\mathrm{b}}, \mathrm{CD} 45.2\right)$ donor to MHC-matched B6/ SJL (H-2D $\left.{ }^{\mathrm{b}}, \mathrm{CD} 45.1\right)$ recipient $(46,56)$ or from C57BL/6 donor to MHC-mismatched BALB/c recipient models (46).

Many characteristic features of acute and chronic GVHD in humans can be reflected by any murine model, although no single murine model captures the entire spectrum of abnormalities observed in humans, just as no single patient can represent the full spectrum of abnormalities that can be caused by the disease. Establishing murine models of acute and chronic GVHD does not require any specific donor and recipient combination. The key is to adjust the number of donor T cells in the graft to allow the recipients to survive acute phase, such that inflammation in acute GVHD can evolve into the myriad features unique to chronic GVHD.

\section{AUTOREACTIVE PATHOGENIC CD4 ${ }^{+} \mathrm{T}$ CELLS IN CHRONIC GVHD ARE DERIVED FROM BOTH MATURE CD4 ${ }^{+}$T CELLS IN THE GRAFT AND DE NOVO-GENERATED CD4 $^{+}$T CELLS IN THE THYMUS}

The diversity of TCRs are randomly generated by VDJ recombination during positive selection in the thymus, and autoreactive $\mathrm{T}$ cells in healthy thymus are depleted by negative selection in the thymic medullary mediated by medullary epithelial cells (mTECs) and dendritic cells (DCs). The mTECs express tissue-restricted antigens (TRA) in AIRE- or Fezf2dependent manner (57-59). The CD11c $\mathrm{c}^{+} \mathrm{DCs}$ in the thymic medullary include $\mathrm{CD} 11 \mathrm{c}^{+} \mathrm{B} 220^{+} \mathrm{PDCA}-1^{+}$plasmacytoid DCs 
TABLE 1 | Summary of murine models of CGVHD.

\begin{tabular}{|c|c|c|c|c|c|c|c|}
\hline Donor strain & $\begin{array}{l}\text { Recipient } \\
\text { strain }\end{array}$ & $\begin{array}{l}\text { Conditioning } \\
\text { regiment }\end{array}$ & Genetics & $\begin{array}{l}\text { Main cell type } \\
\text { contributing to } \\
\text { phenotype }\end{array}$ & Cell type and dose & Outcome & Reference \\
\hline C57BL/6 $\left(\mathrm{H}-2^{\mathrm{b}}\right)$ & $\mathrm{BALB} / \mathrm{C}\left(\mathrm{H}-2^{\mathrm{d}}\right)$ & 850 cGy & $\begin{array}{l}\text { Mismatched for } \mathrm{MHCl} \text {, } \\
\text { MHCll, and miHAs }\end{array}$ & $\begin{array}{l}\mathrm{CD}^{+}, \mathrm{CD} 8^{+} \mathrm{T} \text {, and } \\
\mathrm{B} \text { cells }\end{array}$ & $\begin{array}{l}2.5 \times 10^{6} \mathrm{~T} \text {-cell-depleted }(\mathrm{TCD}) \\
\text { BM cells and } 0.5-1.25 \times 10^{6} \\
\text { unfractionated spleen cells or } 0.5 \\
\times 10^{6} \mathrm{CD}^{+} \text {or } 0.5-5 \times 10^{6} \\
\mathrm{CD} 8^{+} \mathrm{T} \text { cells }\end{array}$ & $\begin{array}{l}\text { Systemic disease including (1) damages in } \\
\text { the acute and chronic GVHD overlapping } \\
\text { targets such as thymus, gut, liver, lung, } \\
\text { and skin, as well as chronic GVHD } \\
\text { prototypical targets salivary and lacrimal } \\
\text { glands; (2) increased serum autoantibodies } \\
\text { and tissue antibody deposition; (3) } \\
\text { collagen deposition and fibrosis in target } \\
\text { organ tissues. }\end{array}$ & $\begin{array}{l}\text { Wu et al. (46) and Kong } \\
\text { et al. (47) }\end{array}$ \\
\hline C57BL/6 $\left(\mathrm{H}-2^{\mathrm{b}}\right)$ & $\mathrm{B} 10 \mathrm{BR}\left(\mathrm{H}-2^{\mathrm{k}}\right)$ & $\begin{array}{l}\text { Cyclophosphamide- } \\
\text { treated (120 mg/kg/ } \\
\text { day, days }-3 \text { and } \\
-2) \text {, irradiated ( } 8.3 \\
\text { Gy by radiograph, } \\
\text { day }-1)\end{array}$ & $\begin{array}{l}\text { Mismatched for } \mathrm{MHCl} \text {, } \\
\text { MHCll, and miHAs }\end{array}$ & $\mathrm{CD}^{+}{ }^{+}$and $\mathrm{CD} 8^{+} \mathrm{T}$ & $\begin{array}{l}\text { TCD-BM and } 0.75 \times 10^{5} \text { purified } \\
\text { splenic T cells }\end{array}$ & Fibrosis with bronchiolitis obliterans & Katelyn Paz et al. (49) \\
\hline$L P / J\left(H-2^{b}\right)$ & $\mathrm{C} 57 \mathrm{BL} / 6\left(\mathrm{H}-2^{\mathrm{b}}\right)$ & $900-1,100$ cGy & $\begin{array}{l}\text { MHC-matched and miHA- } \\
\text { mismatched }\end{array}$ & $\mathrm{CD}^{+}{ }^{+}$and $\mathrm{CD} 8^{+} \mathrm{T}$ & $\begin{array}{l}\text { Whole spleen }\left(10 \times 10^{6}\right) \text { and } \\
\text { TCD-BM }\left(2.5 \times 10^{6}\right)\end{array}$ & Skin scleroderma & $\begin{array}{l}\text { Deng et al. (50), Hamilton } \\
\text { and Parkman (51), and } \\
\text { DeClerck et al. (52) }\end{array}$ \\
\hline $\mathrm{DBA} / 2\left(\mathrm{H}-2^{\mathrm{d}}\right)$ & $\mathrm{BALB} / \mathrm{c}\left(\mathrm{H}-2^{\mathrm{d}}\right)$ & 650 cGy & $\begin{array}{l}\text { MHC-matched and miHA- } \\
\text { mismatched }\end{array}$ & $\mathrm{CD}^{+} \mathrm{T}$ and $\mathrm{B}$ cells & $2.5-10 \times 10^{7}$ whole spleen cells & $\begin{array}{l}\text { Autoantibodies; skin scleroderma; kidney } \\
\text { damage }\end{array}$ & $\begin{array}{l}\text { Zhang et al. (53) and Zhao } \\
\text { et al. (54) }\end{array}$ \\
\hline B10D2 $\left(H-2^{d}\right)$ & BALB/c $\left(H-2^{d}\right)$ & 850 cGy & $\begin{array}{l}\text { MHC-matched and miHA- } \\
\text { mismatched }\end{array}$ & $\mathrm{CD}^{+}{ }^{+}$and $\mathrm{CD} 8^{+} \mathrm{T}$ & $\begin{array}{l}\text { Whole spleen }\left(10 \times 10^{6}\right) \text { and } \\
\text { TCD-BM }\left(2.5 \times 10^{6}\right)\end{array}$ & Skin scleroderma? Systemic disease? & $\begin{array}{l}\text { Deng et al. (50), Korngold } \\
\text { and Sprent (27), and } \\
\text { Eyrich et al. (55) }\end{array}$ \\
\hline $\begin{array}{l}\mathrm{C} 3 \mathrm{H} . S W(\mathrm{H}- \\
\left.2 \mathrm{D}^{\mathrm{b}}, \mathrm{CD} 45.2\right)\end{array}$ & $\begin{array}{l}\text { C57BL/6SJL } \\
\text { (B6/SJL, H-2D } \\
\text { CD45.1) }\end{array}$ & 1,000 cGy & $\begin{array}{l}\text { MHC-matched and miHA- } \\
\text { mismatched }\end{array}$ & Naiive $\mathrm{CD} 8^{+} \mathrm{T}$ & $\begin{array}{l}\text { TCD-BM }\left(5 \times 10^{6}\right) \text { and } \\
\text { CD44 }{ }^{\text {low }} \mathrm{CD}^{+} \text {T cells }\left(2 \times 10^{6}\right)\end{array}$ & $\begin{array}{l}\text { Systemic disease including thymus, skin, } \\
\text { liver, and gastrointestinal tract damage. }\end{array}$ & Zhang et al. (56) \\
\hline
\end{tabular}


(pDCs), $C D 8^{+}$SIRP $\alpha^{-}$thymus-resident DCs (tDCs), and $\mathrm{CD}^{-}{ }^{-} \mathrm{SIRP} \alpha^{+}$migratory DCs (mDCs) (60-62). TRA from mTECs can be picked up by thymic DCs, and TRA from periphery tissues can be brought into the thymus by $\mathrm{mDCs}$ (59). pDCs and tDCs augment thymic negative selection with limited impact on Treg generation; in contrast, mDCs augment both negative selection and tTreg generation in the thymus (6063). The mTEC- and DC-mediated negative selection deletes most of the autoreactive thymocytes; however, the deletion is not $100 \%$, and a small portion of the autoreactive T cells is exported to the periphery (64). The residual autoreactive $\mathrm{T}$ cells in the periphery of healthy individuals are well regulated and controlled by peripheral tolerance mechanisms consisting of regulatory $\mathrm{T}$ cells and tolerogenic DCs (65).

Residual autoreactive $\mathrm{T}$ cells in the graft from healthy donors are expanded after allo-HCT due to breakdown of tolerance mechanisms. In murine models, as depicted in Figure 1, early after allo-HCT, donor $\mathrm{T}$ cells including the residual autoreactive $\mathrm{T}$ cells in the graft are activated by host-type APCs and differentiate into Th/Tcl cells, and they infiltrate GVHD target tissues including gut, liver, lung, skin, thymus, and bone marrow to mediate acute GVHD. Autoreactive $\mathrm{CD} 4^{+} \mathrm{T}$ cells express promiscuous TCRs that cross-react with both self-MHC-antigen complex and allo-MHC-antigen complex (66). Since autoimmune-like chronic GVHD can be induced in thymectomized and athymic recipients (53), the autoreactive $\mathrm{CD}^{+} \mathrm{T}$ cells in those recipients are most likely derived from the residual autoreactive $\mathrm{CD}^{+} \mathrm{T}$ cells in the graft that expanded during alloimmune responses $(53,54)$. The autoreactive $\mathrm{CD} 4^{+} \mathrm{T}$ cells recognize both donor antigen-MHC complex and host
antigen-MHC complex, such that they first act as alloreactive T cells and are activated by host-type APCs, and then they act as autoreactive $\mathrm{T}$ cells and are expanded by donor-type APCs, particularly by the activated donor-type B cells presenting donor- or host-type antigens (67).

The autoreactive $\mathrm{CD} 4^{+} \mathrm{T}$ cells in chronic GVHD recipients are also derived from de novo-generated $\mathrm{CD}^{+} \mathrm{T}$ cells from GVHD-damaged thymus (46). The thymus of allo-HCT recipients can be damaged by condition regimen and GVHD. The thymus damage by conditioning regimen alone can recover in an IL-22-dependent manner (68). Alloreactive $\mathrm{CD}^{+}{ }^{+} \mathrm{T}$ and $\mathrm{CD}^{+} \mathrm{T}$ cells mediate damage of mTECs that mediate negative selection of autoreactive $\mathrm{T}$ cells $(34,46,69)$. Although donortype DCs augment negative selection of autoreactive antidonor and antihost $\mathrm{T}$ cells in non-GVHD recipients with mixed or complete chimerism $(70,71)$, donor-type DCs no longer augment negative selection of the autoreactive $\mathrm{T}$ cells in GVHD recipients due to loss or dysfunction of donor-type DCs $(46,72)$. Therefore, damage of thymus, especially by GVHD leads to an increased generation of autoreactive $T$ cells.

Autoreactive $\mathrm{CD}^{+} \mathrm{T}$ cells in chronic GVHD recipients include those derived from the mature $\mathrm{T}$ cells in the graft or those from de novo-generation in the damaged thymus. In the recipients with overt acute and chronic GVHD, majority of pathogenic $\mathrm{CD}^{+} \mathrm{T}$ cells are from donor-type $\mathrm{CD} 4^{+} \mathrm{T}$ cells from the graft $(46,47)$. This may result from rapid destruction of thymus by acute GVHD that ends the thymic production. However, in the recipients transplanted with sorted $\mathrm{CD}^{+} \mathrm{T}$ cells and that developed little acute GVHD, de novo-generated donor-type $\mathrm{CD} 4^{+} \mathrm{T}$ cells are required for induction of chronic GVHD (46). The autoreactive $\mathrm{CD}^{+} \mathrm{T}$ cells from both

\section{Gated from $\mathrm{H} 2 \mathrm{~Kb}^{+} \mathrm{TCR}{ }^{+} \mathrm{CD} 4^{+} \mathrm{T}$}
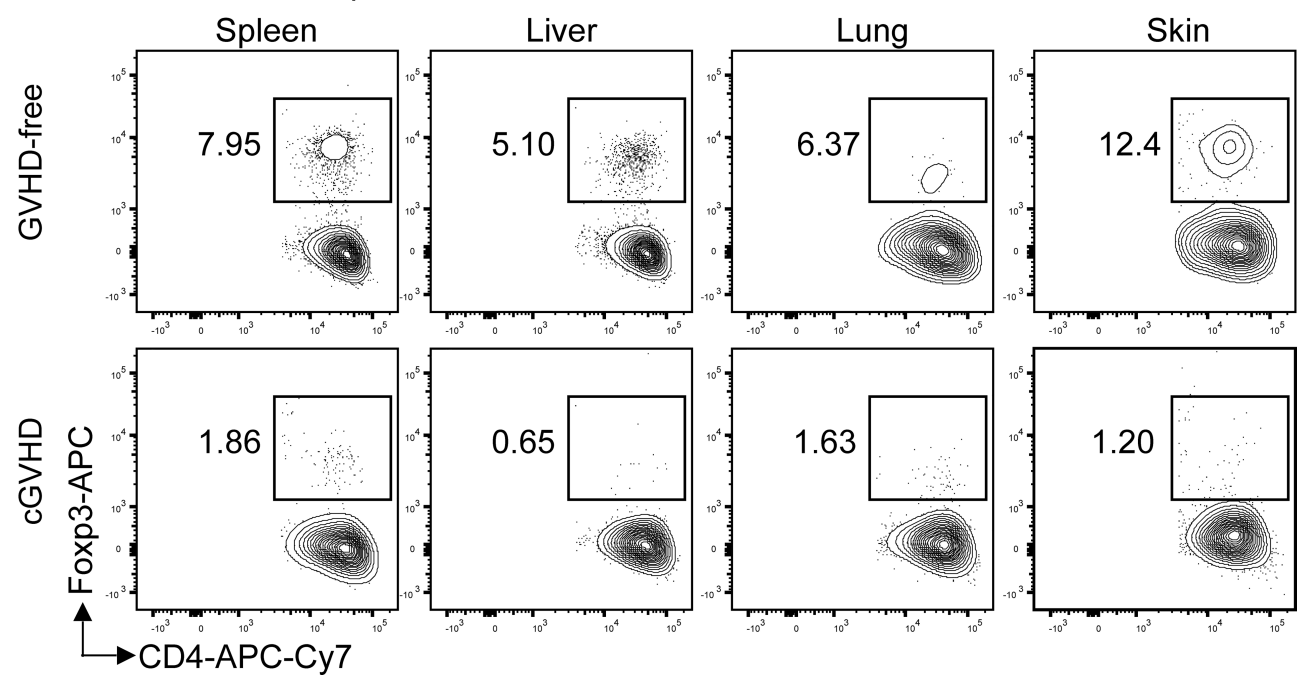

FIGURE 1 | Loss of Foxp3 ${ }^{+} \mathrm{CD}^{+}$Treg cells in the target tissues of chronic GVHD recipients. Lethal TBI-conditioned BALB/c recipients were given T-cell-depleted bone marrow cells (TCD-BM, $2.5 \times 10^{6}$ ) only from C57BL/6 donors as GVHD-free control or given TCD-BM plus spleen cells $\left(1 \times 10^{6}\right)$ for induction of chronic GVHD. Sixty days after HCT, the spleen, liver, lung, and skin tissue mononuclear cells were stained with anti-H-2K ${ }^{b}$, TCRb, CD4, and FoxP3. The gated donor-type $\mathrm{H}-2 \mathrm{~K}^{\mathrm{b}+} \mathrm{CD}^{+} \mathrm{TCR}^{+} \mathrm{T}$ cells are shown in CD4 versus Foxp3. The FoxP3 ${ }^{+}$Treg cells are boxed, and the percentage of the Treg cells among the CD4 ${ }^{+} \mathrm{T}$ cells is shown beside the box. One representative is shown of four recipients in each group. 
sources recognize donor antigen-MHC complex and host antigenMHC complex, and they interact with autoreactive B cells to produce autoantibodies that further damaged the thymus and causes lymphopenia in chronic GVHD recipients $(46,50,67,73)$. Therefore, the autoreactive $\mathrm{CD} 4^{+} \mathrm{T}$ cells derived from the preexisting autoreactive $\mathrm{CD} 4^{+} \mathrm{T}$ cells in the graft play a major role in mediating chronic GVHD pathogenesis in recipients with overt acute and chronic GVHD, and the de novo-generated autoreactive $\mathrm{CD}^{+} \mathrm{T}$ cells from damaged thymus play a major role in chronic GVHD pathogenesis in recipients with little prior acute GVHD.

\section{CHRONIC GVHD PATHOGENESIS DOES NOT REQUIRE GERMINAL CENTERS AND ITS ONSET IS ASSOCIATED WITH DESTRUCTION OF LYMPHO-FOLLICLES AND GERMINAL CENTERS}

Patients with active chronic GVHD have marked reduction of PD- $1{ }^{\text {hi }} \mathrm{CXCR} 5{ }^{+} \mathrm{CD} 4{ }^{+}$follicular $\mathrm{T}$ helper cells (Tfh) among peripheral blood mononuclear cells (PBMC), but high serum concentrations of IgG autoantibodies and CXCL13, the ligand of CXCR5 $(13,74)$, suggesting intense T helper activity for B cells. The results were interpreted to indicate that $\mathrm{Tfh}$ had been recruited into germinal centers of lymphoid follicles in secondary lymphoid organs, consistent with previous preclinical studies showing that chronic GVHD onset was associated with enlarged germinal centers in some murine models of chronic GVHD (74, 75). However, this interpretation conflict with observations that patients with chronic GVHD usually have lymphopenia (76-79), and that somatic hypermutation (SHM) in the memory B cells is low at 1 year after HCT $(80,81)$.

SHM takes place in the B cells during differentiation in the GCs (82-84). With variety murine models, we have demonstrated that chronic GVHD onset is associated with destruction of lymphoid follicles and GCs in the spleen. In addition, we showed that GC formation is not required for induction of chronic GVHD, because recipients with an absence of BCL6 in donor B cells that could not form GCs nonetheless developed chronic GVHD (50, 73). Recipients with overt chronic GVHD had no detectable GCs, Tfh cells, or GC B cells, although recipients with mild chronic GVHD had remnants of GCs, residual Tfh, and GC B cells $(47,50,73)$.

\section{EXTRAFOLLICULAR PSGL $1{ }^{10} \mathrm{CD} 4{ }^{+} \mathrm{T}$ AND B CELL INTERACTIONS AUGMENT AUTOIMMUNE DEVELOPMENT AND CHRONIC GVHD PATHOGENESIS}

P-selectin glycoprotein ligand 1 (PSGL1, also known as CD162) is an adhesion and coinhibitory receptor; PSGL1 are widely expressed in almost all $\mathrm{T}$ cells in the blood and binds to $\mathrm{E}-$ selectin and P-selectin $(85,86)$. A subset of activated $\mathrm{CD} 4^{+} \mathrm{T}$ cells in the spleen of SLE mice downregulate expression of PSGL1 and become CD $44^{\text {hi }}{ }^{\mathrm{C} D} 62 \mathrm{~L}^{-} \mathrm{PSGL} 1^{\mathrm{lo}} \mathrm{CD} 4^{+} \mathrm{T}$ (PSGL $1{ }^{\text {lo }} \mathrm{CD}^{+} \mathrm{T}$ ) cells $(87)$. PSGL $1^{\mathrm{lo}} \mathrm{CD}^{+}{ }^{+} \mathrm{T}$ cells localize at the extrafollicular sites of systemic lupus mice and express high levels of CXCR4, ICOS, and CD40L without expression of CXCR5 (88). We served that chronic GVHD onset is associated with expansion of PSGL1 ${ }^{\text {lo }} \mathrm{CD}^{+}{ }^{+} \mathrm{T}$ helpers in the GVHD target tissues $(47,50)$. Extrafollicular PSGL $1{ }^{10} \mathrm{CD}_{4}{ }^{+} \mathrm{T}$ helpers for autoreactive B cells were first identified as $\mathrm{CD}^{+} \mathrm{T}$ helpers in the spleen of systemic lupus mice (87). The differentiation of the $\mathrm{PSGL} 1^{1 \mathrm{lo}} \mathrm{CD} 4^{+} \mathrm{T}$ helpers in chronic GVHD recipients depends on the IL-6R-Stat3-BCL6 pathway, and Stat 3 or BCL6 deficiency in donor $\mathrm{CD} 4^{+} \mathrm{T}$ cells prevented expansion of the PSGL $1{ }^{\mathrm{lo}} \mathrm{CD} 4^{+} \mathrm{T}$ cells in GVHD target tissues $(47,50)$. The PSGL1 ${ }^{10} \mathrm{CD} 4^{+} \mathrm{T}$ cell interaction with $\mathrm{B}$ cells results in autoantibody production and augmented thymus damage early after HCT (50). Prevention of PSGL $1{ }^{\mathrm{lo}} \mathrm{CD} 4^{+} \mathrm{T}$ expansion by BCL6 or Stat 3 deficiency and by blockade of ICOS or PD-1 interaction with ICOSL or PD-L2 on B cells markedly reduced serum concentrations of autoantibodies and decreased the severity of chronic GVHD $(47,50)$. In addition, we observed that chronic GVHD tissues had high levels of CXCL13 as measured with liver tissue homogenates, and PSGL1 ${ }^{10} \mathrm{CD} 4^{+} \mathrm{T}$ cells expressed high levels of CXCL13 mRNA (Kong, unpublished data). Taken together, these results suggest that the low number of Tfh cells in the PBMC of active chronic GVHD patients is unlikely due to redistribution of the Tfh cells into GCs in the lymphoid follicles, and it is more likely due to the destruction of GCs and lymphoid follicles. The high concentrations of CXCL13 and IgG autoantibodies in the serum of the patients may result from expansion of extrafollicular $\mathrm{CD} 4^{+} \mathrm{T}$ and $\mathrm{B}$ cells in GVHD target tissues.

\section{EXTRAFOLLICULAR PSGL $1{ }^{\circ} \mathrm{CD} 4^{+} \mathrm{T}$ HELPER CELLS ARE TISSUE RESIDENT MEMORY T CELLS THAT INTERACT WITH MEMORY B CELLS IN THE GVHD TARGET TISSUES DURING CHRONIC GVHD PATHOGENESIS}

As mentioned above, extrafollicular PSGL1 ${ }^{\mathrm{lo}} \mathrm{CD} 4^{+} \mathrm{T}$ cells were identified in the spleen of systemic lupus more than a decade ago (87), but their role in human systemic lupus pathogenesis remains unknown. We have recently found that PSGL $1{ }^{\text {lo }} \mathrm{CD} 4{ }^{+} \mathrm{T}$ cells were not detectable in the peripheral blood of murine or human chronic GVHD recipients (47). Instead, they were $\mathrm{CD}^{+}$tissue-resident memory $\mathrm{T}(\mathrm{Trm})$ cells with upregulated expression of CD69, CXCR6, P2RX7, and PD-1 and downregulated expression of Klf2, S1PR1, and CCR7 (47), consistent with Trm cell phenotype reported by others in infection and autoimmune colitis models (89). These observations explain why extrafollicular PSGL1 ${ }^{10} \mathrm{CD}^{+}$ $\mathrm{T}$ cells are not detectable in the peripheral blood of mice or patients with chronic GVHD. This may also explain why their role 
in the pathogenesis of systemic lupus has not been investigated in humans.

The PSGL $1{ }^{\text {lo }} \mathrm{CD} 4{ }^{+}$Trm cells interact with memory B cells in the GVHD target tissues in murine recipients, humanized murine recipients, and in the liver of cGVHD patients (47). The humanized murine model was established by injection of HLA-A2 $2^{-} \mathrm{DR}^{-}$human PBMC into $\mathrm{MHC}^{-1-} \mathrm{HLA}-\mathrm{A} 2^{+} \mathrm{DR} 4^{+}$ NSG mice (47). The PSGL $1{ }^{\text {lo }} \mathrm{CD} 4^{+} \mathrm{T}$ cells were juxtaposed to memory $\mathrm{B}$ cells in the liver of murine recipients, humanized murine recipients, and patients with chronic GVHD, as indicated by immunofluorescent and immunohistochemistry staining of the tissue-infiltrating cells (47). Sorted PSGL $1^{\mathrm{lo}} \mathrm{CD} 4^{+} \mathrm{T}$ cells from GVHD target tissues (liver and lung) of murine and humanized murine recipients augmented in vitro differentiation of syngeneic or autologous memory B cells but not naïve B cells into IgG-producing plasma cells in a manner that depended on PD-1/PD-L2 interaction and IL-21 (47).

On the other hand, the expansion of human memory $B$ and plasma B cells in the GVHD target tissue liver and lung of humanized murine recipients was associated with expansion of PSGL $1{ }^{\text {lo }} \mathrm{CD}^{+}{ }^{+} \mathrm{T}$ cells, but little $\mathrm{B}$ cell activation and expansion were observed in the $\mathrm{MHC}^{-1-}$ control recipients (47). We also observed that PD-1 deficiency in donor T cells and PD-L2 deficiency in donor $\mathrm{B}$ cells were associated with reduction of serum anti-dsDNA, reduction of tissue IgG deposition, reduction of tissue fibrosis, and reduction of chronic GVHD severity (47). Finally, sorted PD- $1^{+/+}$or PD- $1^{-/-}$PSGL $1^{\text {lo }} \mathrm{CD} 4^{+} \mathrm{T}$ and PSGL $1{ }^{\text {hi }} \mathrm{CD}^{+} \mathrm{T}$ cells from liver and lung GVHD target tissues were adoptively transferred into GVHD-free adoptive recipients with $\mathrm{PD}-\mathrm{L}^{+/+}$or PD-L2 ${ }^{-/-} \mathrm{B}$ cells. The results showed that PSGL $1^{\text {lo }}$ and PSGL1 ${ }^{\text {hi }} \mathrm{CD}^{+}$memory $\mathrm{T}$ cells preferentially migrated back to the original GVHD target tissues in the adoptive recipients, but only PSGL $1{ }^{\text {lo }} \mathrm{CD} 4^{+} \mathrm{T}$ cells augmented expansion of plasma cells in the GVHD target tissues and increased serum concentration of total IgG and anti-dsDNAIgG in a manner that required PD-1 interaction with PD-L2 (47). Taken together, these results show that PSGL $1{ }^{\text {lo }} \mathrm{CD} 4^{+}$Trm cell interaction with memory B cells in GVHD target tissues contributes to perpetuation of chronic GVHD pathogenesis.

\section{EXTRAFOLLICULAR PSGL $1^{10} \mathrm{CD}^{+} \mathrm{T}$ HELPERS ARE DERIVED FROM PSGL1 ${ }^{\text {hi }}$ CD4 ${ }^{+} T$ CELLS IN THE GRAFT IN AN IL-6-STAT3-BCL6-DEPENDENT MANNER}

We observed that all peripheral blood $\mathrm{CD} 4^{+} \mathrm{T}$ cells from healthy murine and human donors were PSGL1 ${ }^{\text {hi }}$ (47). After transplantation into murine and humanized murine recipients, a portion $(5 \%-20 \%)$ of PSGL1 ${ }^{\text {hi }} \mathrm{CD}^{+}{ }^{+} \mathrm{T}$ cells differentiated into PSGL $1{ }^{\text {lo }} \mathrm{CD} 4^{+}$Trm cells in an IL-6-Stat3-dependent manner (47) because Stat 3 deficiency in the $\mathrm{CD} 4^{+} \mathrm{T}$ cells and administration of blocking anti-IL-6R mAb markedly reduced the expansion of PSGL $1{ }^{\text {lo }} \mathrm{CD} 4^{+} \mathrm{T}$ cells in the GVHD target tissues of murine recipients (47). We have also observed expansion of de novo- generated PSGL $1{ }^{\text {lo }} \mathrm{CD} 4^{+} \mathrm{T}$ cells in chronic GVHD recipients induced by sorted donor $\mathrm{CD}^{+} \mathrm{T}$ cells (Kong, unpublished data). These results indicate that PSGL $1{ }^{\mathrm{lo}} \mathrm{CD} 4^{+} \mathrm{T}$ differentiation is similar to prefollicular $\mathrm{CD} 4^{+} \mathrm{T}$ differentiation that is controlled by IL-6-Stat3-BCL6 pathways $(50,84)$.

\section{CIRCULATING ANTIBODIES AUGMENT SCLERODERMATOUS CUTANEOUS CHRONIC GVHD}

In humans, autoantibodies such as PDGF-1 have been associated with increased severity of cutaneous chronic GVHD (90). We found that high serum concentrations of autoantibody were associated increased IgG deposition and fibrosis in the skin tissues of murine and humanized murine recipients (47). Donor-derived IgG antibodies were required to perpetuate cutaneous chronic GVHD (73). Unexpectedly, we found no PSGL $1^{\mathrm{lo}} \mathrm{CD} 4^{+} \mathrm{T}$ or B cells in the skin tissues of murine or humanized murine recipients with chronic GVHD, although PSGL1 ${ }^{\text {lo }} \mathrm{CD} 4^{+} \mathrm{T}$ and memory B cells were present in the liver and lung (47). Studies are in progress to determine whether B cells or PSGL $1{ }^{\text {lo }} \mathrm{CD} 4^{+} \mathrm{T}$ cells are present in the skin of patients with cutaneous chronic GVHD.

Taken together, the preclinical results indicate that circulating autoantibodies contribute to pathogenesis of cutaneous chronic GVHD. We also observed that circulating IgG antibodies augmented DC secretion of IL-23 and expansion of Th17 cells in the skin of chronic GVHD mice (73). MacDonald et al. showed that in an IL-17-dependent cutaneous chronic GVHD model, donor-type $\mathrm{F} 4 / 80^{+} \mathrm{CSF}-1 \mathrm{R}^{+}$type 2 macrophages augmented cutaneous chronic GVHD in a G-CSF but not GMCSF-dependent manner, in which the macrophages mediate fibrosis via their production of TGF- $\beta$ (91). Whether circulating IgG autoantibodies regulate the differentiation and expansion of type 2 macrophages during cutaneous GVHD remains to be studied.

\section{LOSS OF FUNCTIONAL THYMIC DCS AND PERIPHERAL PD-L1 ${ }^{\text {hi }}$ PLASMACYTOID DCS MAY CONTRIBUTE TO LOSS OF FOXP ${ }^{+}{ }^{+}$CD4 ${ }^{+}$TREG CELLS IN CHRONIC GVHD TARGET TISSUES}

Chronic GVHD patients had markedly low percentages of Foxp $3^{+} \mathrm{CD}^{+}$regulatory $\mathrm{T}$ (Treg) cells in the blood (92). Lowdose IL-2 preferentially expanded $\mathrm{CD} 4^{+}$Treg cells by binding to high affinity IL-2R $\alpha$ (CD25) and ameliorated clinical manifestation of chronic GVHD (93-95). Consistently, in a chronic GVHD model with DBA/2 donors and BALB/c recipients, loss of $\mathrm{CD} 4^{+}$Treg cells was associated with chronic GVHD onset, and infusion of donor-type Treg cells prevented the disease onset or ameliorated the progression of chronic GVHD $(96,97)$. Importantly, we observed that percentages of Treg cells were high among $\mathrm{CD} 4^{+} \mathrm{T}$ cells in the spleen, liver, 
lung, and skin of healthy donor or GVHD-free recipients, but few Treg cells were found among $\mathrm{CD} 4^{+} \mathrm{T}$ cells in the same tissues from mice with chronic GVHD (Figure 1).

The low number of $\mathrm{CD}^{+}$Treg cells may result from reduced thymic Treg (tTreg) output, reduced differentiation of conventional $\mathrm{CD}^{+} \mathrm{T}$ (Tcon) cells into peripheral Treg (pTreg) cells, and reduced Treg expansion and survival in the periphery. Thymic damage or engraftment with $\mathrm{MHCII}^{-/-}$donor DCs resulted in reduced generation of tTreg cells in GVHD recipients $(98,99)$, while engraftment of donor-type DCs increased donor- and host-type thymic tTreg generation in GVHD-free MHC-mismatched or haploidentical mixed chimeras $(71,100,101)$. Plasmacytoid DCs that express high levels of PD-L1 (PD-L1 ${ }^{\text {hi }}$ pDCs) augment Tcon differentiation into pTreg cells in a PD-L1/PD-1 interaction-dependent manner (102-104). DC PD-L1 interaction with CD80 on Treg cells also augments Treg survival and expansion (96). GVHD in bone marrow reduced the production of $\mathrm{PD}-\mathrm{L1}^{+} \mathrm{pDCs}$, leading to reduced generation and expansion of Treg cells (105). Therefore, loss of functional DCs in the thymus and loss of bone marrow generation of $\mathrm{PD}-\mathrm{L} 1^{\mathrm{hi}} \mathrm{pDCs}$ may contribute to the marked reduction of Treg cells in the chronic GVHD recipients, and prevention of thymus and bone marrow GVHD as well as restoration of bone marrow production of $\mathrm{pDCs}$ might reverse chronic GVHD.

\section{CONCLUSIONS}

In summary, with murine models of chronic GVHD, we have found that extrafollicular $\mathrm{CD} 4^{+} \mathrm{T}$ and $\mathrm{B}$ interactions and $\mathrm{CD} 4^{+}$ Trm cells in the GVHD target tissues play critical roles in chronic GVHD pathogenesis, and these findings have been linked to chronic GVHD pathogenesis in humans through studies with humanized $\mathrm{MHC}^{-/-} \mathrm{HLA}-\mathrm{A} 2^{+} \mathrm{DR} 4^{+} \mathrm{NSG}$ mice and patient GVHD target tissues (47). These studies have provided new insights into chronic GVHD pathogenesis in humans.

As depicted in the diagram (Figure 2), we propose how donor $\mathrm{CD}^{+} \mathrm{T}$ cells mediate autoimmune-like chronic GVHD pathogenesis. Step 1, early after allo-HCT, in the lymphoid

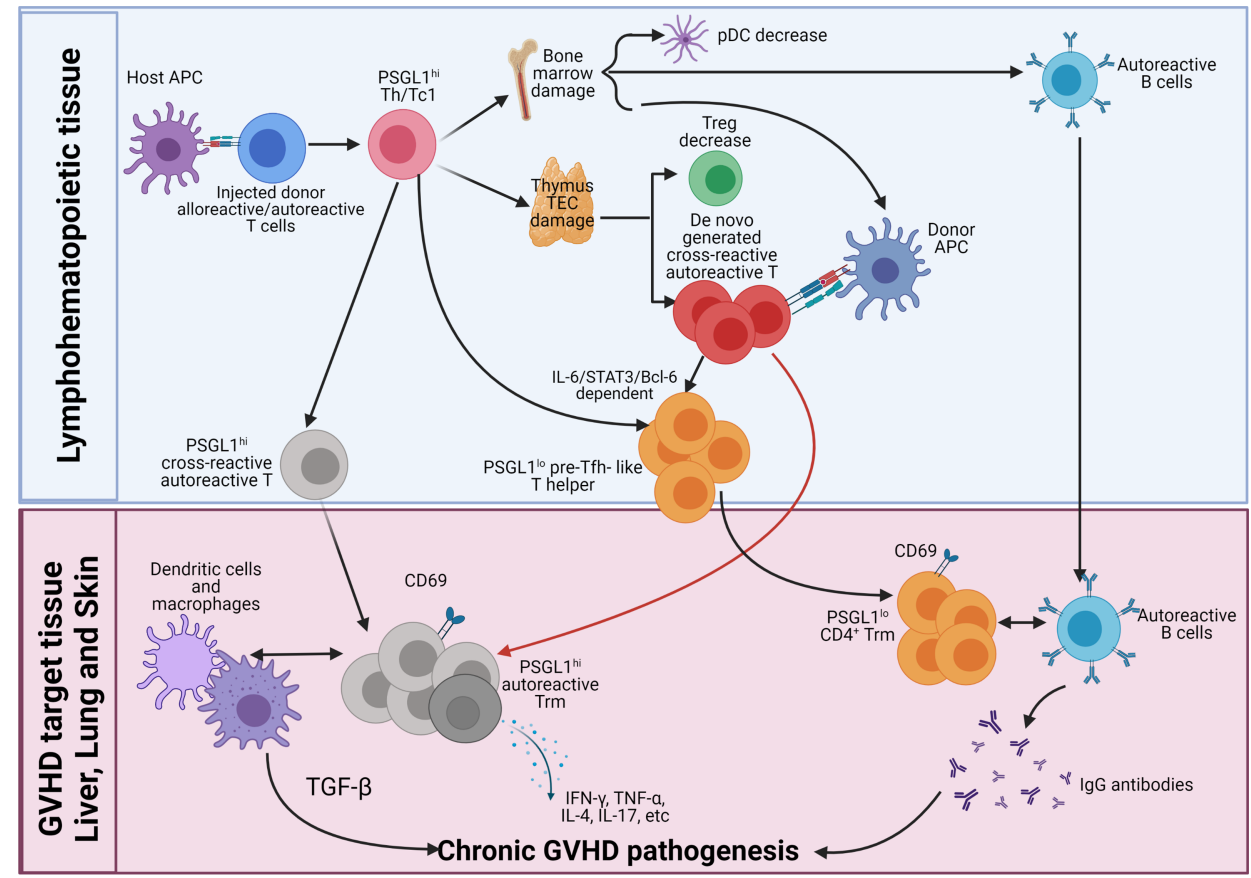

FIGURE 2 | Pathogenesis of chronic GVHD. Early after allo-HCT, donor-type CD4 $4^{+}$, and CD8 ${ }^{+}$T cells including autoreactive CD4 ${ }^{+}$T cells are activated by host APCs in the lymphoid tissues. The majority of the injected alloreactive T cells differentiate into PSGL $1^{\text {hi }}$ Th1/Tc1 cells to cause acute GVHD. At the same time, some of the autoreactive $\mathrm{CD} 4^{+} \mathrm{T}$ cells differentiate into PSGL $1^{\mathrm{lo}} \mathrm{CD} 4^{+}$pre-Tfh-like cells via IL-6-Stat3-BCL6 pathway, and they interact with activated donor B cells to augment antibody production, and some of them remain PSGL1 ${ }^{\text {hi }}$. The Th1/Tc1 cells infiltrate GVHD target tissues including thymus and bone marrow. Damage of thymic medullary epithelial cells (mTECs) leads to decreased generation of thymic Tregs (tTreg) cells and increased release of autoreactive T cells that are crossreactive with donor antigen-MHC complex and host antigen-MHC complex. Damage of bone marrow microenvironment results in increased production of autoreactive B cells and reduced production of tolerogenic plasmacytoid dendritic cells (pDCs). Acute GVHD destroys lymphoid tissues. As acute GVHD subside into chronic GVHD, alloreactive pathogenic memory T, especially $\mathrm{CD}^{+}{ }^{+}$memory T cells, that can cross-react with donor APCs become autoreactive CD4 ${ }^{+} \mathrm{T}$ cells and gather in the GVHD target tissue. The de novo-generated autoreactive $\mathrm{CD} 4^{+} \mathrm{T}$ cells from damaged thymus also infiltrate the GVHD target tissues. The autoreactive $\mathrm{CD}^{+} \mathrm{T}$ cells from both sources interact with donor-type APCs and become $\mathrm{CD}_{6} 9^{+}$tissue resident memory $\mathrm{T}(\mathrm{Trm})$ cells in the tissues. The PSGL1 ${ }^{\text {hi }}$ autoreactive Trm cells interact with DCs and macrophages to mediate pathogenesis via their production of cytokines such as TGF- $\beta$, IFN- $\gamma$, TNF- $\alpha$, IL-4, IL-17, and IL-22. The pre-Tfh-like PSGL $1{ }^{10} \mathrm{CD}_{4}{ }^{+}$helper T cells interact with B cells to augment memory B-cell differentiation into plasma cells that produce lgG autoantibodies. IgG autoantibodies enter circulation and deposit in the GVHD target tissues such as skin to augment GVHD pathogenesis. 
tissues, donor $\mathrm{CD}^{+}$and $\mathrm{CD} 8^{+} \mathrm{T}$ cells including cross-reactive residual autoreactive $\mathrm{CD} 4^{+} \mathrm{T}$ cells in the graft act as alloreactive $\mathrm{CD}^{+}$and $\mathrm{CD}^{+} \mathrm{T}$ cells; they are activated by interaction with host-type APCs. The alloreactive $\mathrm{T}$ cells differentiate into PSGL1 $^{\text {hi }}$ Th1/Tc1 cells and infiltrating GVHD target tissues. The small portion of autoreactive $\mathrm{CD} 4^{+} \mathrm{T}$ cells differentiate into $\mathrm{PSGL}^{\mathrm{hi}} \mathrm{CD}^{+}{ }^{+}$memory $\mathrm{T}$ cells and PSGL $1^{\text {lo }} \mathrm{CD} 4^{+}$pre-Tfh-like cells via IL-6-Stat3-BCL6 pathway. The alloreactive Th1/Tc1 cells migrate into and cause damage in the thymus and bone marrow, among other GVHD target tissues such as the liver, lung, and skin. Those alloreactive Th1/Tc1 cells also destroy secondary lymphoid tissues as time goes on. Due to GVHD damage of thymic medullary epithelial cells and defective negative selection, the thymus increases production of autoreactive $\mathrm{CD} 4^{+} \mathrm{T}$ cells that recognize both donor antigenMHC complex and host antigen-MHC complex, as well as reduces production of $\mathrm{CD}^{+}$tTreg cells. Those cross-reactive autoreactive $\mathrm{CD}^{+} \mathrm{T}$ cells are activated in the periphery and infiltrate GVHD target tissues. The GVHD-damaged bone marrow has low production of tolerogenic PD-L1 ${ }^{\text {hi }}$ pDCs, defective negative selection of autoreactive $\mathrm{B}$ cells, and markedly reduced output of B cells and myeloid cells, leading to lymphopenia with relative expansion of autoreactive $B$ cells in the periphery.

Step 2, the cross-reactive autoreactive $\mathrm{CD} 4^{+} \mathrm{T}$ cells derived from the residual autoreactive $\mathrm{CD} 4^{+} \mathrm{T}$ cells in the graft and from de novo-generation in the damaged thymus interact with donortype DCs/macrophages or B cells, leading to their survival and expansion after acute GVHD subsides. The cross-reactive autoreactive $\mathrm{CD}^{+} \mathrm{T}$ cells infiltrate GVHD target tissues and become $\mathrm{CD} 9^{+}$Trm cells. The PSGL1 ${ }^{\text {hi }}$ Th1, Th2, and Th17 cross-reactive autoreactive Trm cells interact with DCs and macrophages to mediate chronic GVHD pathogenesis via their production of cytokines such as TGF- $\beta$, IFN- $\gamma$, TNF- $\alpha$, IL- 4 , IL17, and IL-22. The pre-Tfh-like autoreactive PSGL1 $1^{\text {lo }} \mathrm{CD} 4^{+} \mathrm{T}$ cells become extrafollicular PSGL $1{ }^{\mathrm{lo}} \mathrm{CD} 4^{+}$helper $\mathrm{T}$ cells in the GVHD target tissues (i.e., liver and lung). They attract and interact with autoreactive $\mathrm{B}$ cells in the tissues and become Trm cells. Their interaction with B cells augments memory Bcell differentiation into plasma cells that produce IgG

\section{REFERENCES}

1. Bleakley M, Riddell SR. Molecules and Mechanisms of the Graft-VersusLeukaemia Effect. Nat Rev Cancer (2004) 4(5):371-80. doi: 10.1038/nrc1365

2. Biernacki MA, Sheth VS, Bleakley M. T Cell Optimization for Graft-VersusLeukemia Responses. JCI Insight (2020) 5(9):e134939. doi: 10.1172/ jci.insight. 134939

3. Kassim AA, Savani BN. Hematopoietic Stem Cell Transplantation for Acute Myeloid Leukemia: A Review. Hematol Oncol Stem Cell Ther (2017) 10 (4):245-51. doi: 10.1016/j.hemonc.2017.05.021

4. DeFilipp Z, Advani AS, Bachanova V, Cassaday RD, Deangelo DJ, Kebriaei $\mathrm{P}$, et al. Hematopoietic Cell Transplantation in the Treatment of Adult Acute Lymphoblastic Leukemia: Updated 2019 Evidence-Based Review From the American Society for Transplantation and Cellular Therapy. Biol Blood Marrow Transplant (2019) 25(11):2113-23. doi: 10.1016/ j.bbmt.2019.08.014 autoantibodies that augment local inflammation and fibrosis or enter circulation. The circulating IgG antibodies deposit in the tissues such as skin to augment GVHD pathogenesis.

Finally, lack of tolerogenic pDCs and Treg cells allow the cross-reactive autoreactive $\mathrm{CD} 4^{+}$Trm cells that recognize both donor antigen-MHC complex and host antigen-MHC complex to continuously interact with DCs, macrophages, and B cells to perpetuate chronic GVHD pathogenesis. Therefore, PSGL1 ${ }^{\text {hi }}$ and PSGL $1^{\text {lo }} \mathrm{CD}^{+}{ }^{+}$Trm cells, macrophage, dendritic cells, B cells, and circulating IgG autoantibodies, all contribute to the pathogenesis of chronic GVHD, but $\mathrm{CD}^{+}{ }^{+}$Trm cells play the essential role. Targeting autoreactive $\mathrm{CD} 4^{+}$Trm cells in the GVHD target tissues for treatment of chronic GVHD is under investigation.

We would like to point out that the proposed model of cGVHD pathogenesis is more relevant to chronic GVHD pathogenesis in recipients with obvious acute GVHD. However, in the clinic, some chronic GVHD patients did not have a clear phase of acute GVHD. The origin of the pathogenic $\mathrm{T}$ cells in those patients remains unclear. They may derive from de novo thymus-generated $\mathrm{T}$ cells because our murine model showed that sorted donor $\mathrm{CD} 8^{+}$ T cells induced thymus damage and chronic GVHD in the absence of acute GVHD (46). The roles of Tfh and extrafollicular PSGL $1{ }^{\text {lo }} \mathrm{CD} 4^{+} \mathrm{T}$-cell interaction with $\mathrm{B}$ cells in the pathogenesis of chronic GVHD without obvious acute GVHD remain unclear and are under investigation.

\section{AUTHOR CONTRIBUTIONS}

QS, XK, and DZ wrote the review manuscript. PM critically reviewed and edited the manuscript. All authors contributed to the article and approved the submitted version.

\section{FUNDING}

This work was supported by the National Institutes of Health Grant R01 AI066008 and R01 CA228465 (to DZ).
5. Horowitz MM, Gale RP, Sondel PM, Goldman JM, Kersey J, Kolb HJ, et al. Graft-Versus-Leukemia Reactions After Bone Marrow Transplantation. Blood (1990) 75(3):555-62. doi: 10.1182/blood.V75.3.555.555

6. Weiden PL, Flournoy N, Thomas ED, Prentice R, Fefer A, Buckner CD, et al. Antileukemic Effect of Graft-Versus-Host Disease in Human Recipients of Allogeneic-Marrow Grafts. N Engl J Med (1979) 300(19):1068-73. doi: 10.1056/NEJM197905103001902

7. Zeiser R. Advances in Understanding the Pathogenesis of Graft-VersusHost Disease. Br J Haematol (2019) 187(5):563-72. doi: 10.1111/ bjh. 16190

8. Betts BC, Yu XZ. Editorial: Pathogenesis and Therapy of Graft-Versus-Host Disease. Front Immunol (2019) 10:1797. doi: 10.3389/fimmu.2019.01797

9. Naymagon S, Naymagon L, Wong SY, Mabel Ko H, Renteria A, Levine J, et al. Acute Graft-Versus-Host Disease of the Gut: Considerations for the Gastroenterologist. Nat Rev Gastroenterol Hepatol (2017) 14(12):711-26. doi: 10.1038/nrgastro.2017.126 
10. Zeiser R, Blazar BR. Acute Graft-Versus-Host Disease - Biologic Process, Prevention, and Therapy. N Engl J Med (2017) 377(22):2167-79. doi: 10.1056/NEJMra1609337

11. Dignan FL, Clark A, Amrolia P, Cornish J, Jackson G, Mahendra P, et al. Diagnosis and Management of Acute Graft-Versus-Host Disease. Br J Haematol (2012) 158(1):30-45. doi: 10.1111/j.1365-2141.2012.09129.x

12. Matsuzawa-Ishimoto Y, Hine A, Shono Y, Rudensky E, Lazrak A, Yeung F, et al. An Intestinal Organoid-Based Platform That Recreates Susceptibility to T-Cell-Mediated Tissue Injury. Blood (2020) 135(26):2388-401. doi: 10.1182/blood.2019004116

13. Kuzmina Z, Gounden V, Curtis L, Avila D, Taylor Rnp T, Baruffaldi J, et al. Clinical Significance of Autoantibodies in a Large Cohort of Patients With Chronic Graft-Versus-Host Disease Defined by NIH Criteria. Am J Hematol (2015) 90(2):114-9. doi: 10.1002/ajh.23885

14. Cooke KR, Luznik L, Sarantopoulos S, Hakim FT, Jagasia M, Fowler DH, et al. The Biology of Chronic Graft-Versus-Host Disease: A Task Force Report From the National Institutes of Health Consensus Development Project on Criteria for Clinical Trials in Chronic Graft-Versus-Host Disease. Biol Blood Marrow Transplant (2017) 23(2):211-34. doi: 10.1016/ j.bbmt.2016.09.023

15. Lee SJ. Classification Systems for Chronic Graft-Versus-Host Disease. Blood (2017) 129(1):30-7. doi: 10.1182/blood-2016-07-686642

16. Zeiser R, Blazar BR. Pathophysiology of Chronic Graft-Versus-Host Disease and Therapeutic Targets. N Engl J Med (2017) 377(26):2565-79. doi: 10.1056/NEJMra1703472

17. Socie G, Ritz J. Current Issues in Chronic Graft-Versus-Host Disease. Blood (2014) 124(3):374-84. doi: 10.1182/blood-2014-01-514752

18. Ferrara JL, Levine JE, Reddy P, Holler E. Graft-Versus-Host Disease. Lancet (2009) 373(9674):1550-61. doi: 10.1016/S0140-6736(09)60237-3

19. MacDonald KP, Hill GR, Blazar BR. Chronic Graft-Versus-Host Disease: Biological Insights From Preclinical and Clinical Studies. Blood (2017) 129 (1):13-21. doi: 10.1182/blood-2016-06-686618

20. Inamoto Y, Flowers ME, Sandmaier BM, Aki SZ, Carpenter PA, Lee SJ, et al. Failure-Free Survival After Initial Systemic Treatment of Chronic GraftVersus-Host Disease. Blood (2014) 124(8):1363-71. doi: 10.1182/blood2014-03-563544

21. Schroeder MA, DiPersio JF. Mouse Models of Graft-Versus-Host Disease: Advances and Limitations. Dis Model Mech (2011) 4(3):318-33. doi: 10.1242/dmm.006668

22. Reddy P, Ferrara JLM. Mouse Models of Graft-Versus-Host Disease. Cambridge (MA: StemBook (2008).

23. Storb R, Thomas ED. Graft-Versus-Host Disease in Dog and Man: The Seattle Experience. Immunol Rev (1985) 88:215-38. doi: 10.1111/j.1600065X.1985.tb01160.x

24. Furlan SN, Watkins B, Tkachev V, Cooley S, Panoskaltsis-Mortari A, Betz K, et al. Systems Analysis Uncovers Inflammatory Th/Tc17-Driven Modules During Acute GVHD in Monkey and Human T Cells. Blood (2016) 128 (21):2568-79. doi: 10.1182/blood-2016-07-726547

25. Korngold R, Sprent J. Lethal Graft-Versus-Host Disease After Bone Marrow Transplantation Across Minor Histocompatibility Barriers in Mice. Prevention by Removing Mature T Cells From Marrow. J Exp Med (1978) 148(6):1687-98. doi: 10.1084/jem.148.6.1687

26. Korngold R, Sprent J. Features of T Cells Causing H-2-Restricted Lethal Graft-vs.-Host Disease Across Minor Histocompatibility Barriers. J Exp Med (1982) 155(3):872-83. doi: 10.1084/jem.155.3.872

27. Korngold R, Sprent J. Variable Capacity of L3T4+ T Cells to Cause Lethal Graft-Versus-Host Disease Across Minor Histocompatibility Barriers in Mice. J Exp Med (1987) 165(6):1552-64. doi: 10.1084/jem.165.6.1552

28. Zeng D, Hoffmann P, Lan F, Huie P, Higgins J, Strober S, et al. Unique Patterns of Surface Receptors, Cytokine Secretion, and Immune Functions Distinguish T Cells in the Bone Marrow From Those in the Periphery: Impact on Allogeneic Bone Marrow Transplantation. Blood (2002) 99(4):1449-57. doi: 10.1182/ blood.V99.4.1449

29. Hill GR, Crawford JM, Cooke KR, Brinson YS, Pan L, Ferrara JLM, et al. Total Body Irradiation and Acute Graft-Versus-Host Disease: The Role of Gastrointestinal Damage and Inflammatory Cytokines. Blood (1997) 90 (8):3204-13. doi: 10.1182/blood.V90.8.3204
30. Teshima T, Ordemann R, Reddy P, et al. Acute Graft-Versus-Host Disease Does Not Require Alloantigen Expression on Host Epithelium. Nat Med (2002) 8(6):575-81. doi: 10.1038/nm0602-575

31. Korngold R, Sprent J. Surface Markers of T Cells Causing Lethal Graft-vsHost Disease to Class I vs Class II H-2 Differences. J Immunol (1985) 135 (5):3004-10

32. Nikolic B, Lee S, Bronson RT, Grusby MJ, Sykes M. Th1 and Th2 Mediate Acute Graft-Versus-Host Disease, Each With Distinct End-Organ Targets. J Clin Invest (2000) 105(9):1289-98. doi: 10.1172/JCI7894

33. Beilhack A, Schulz S, Baker J, Beilhack GF, Wieland CB, Herman EI, et al. In Vivo Analyses of Early Events in Acute Graft-Versus-Host Disease Reveal Sequential Infiltration of T-Cell Subsets. Blood (2005) 106(3):1113-22. doi: 10.1182/blood-2005-02-0509

34. Na IK, Lu SX, Yim NL, Goldberg GL, Tsai J, Rao U, et al. The Cytolytic Molecules Fas Ligand and TRAIL are Required for Murine Thymic GraftVersus-Host Disease. J Clin Invest (2010) 120(1):343-56. doi: 10.1172/ JCI39395

35. Zhang Y, Louboutin JP, Zhu J, Rivera AJ, Emerson SG. Preterminal Host Dendritic Cells in Irradiated Mice Prime CD8+ T Cell-Mediated Acute Graft-Versus-Host Disease. J Clin Invest (2002) 109(10):1335-44. doi: 10.1172/JCI0214989

36. Wu Y, Bastian D, Schutt S, Nguyen H, Fu J, Heinrichs J, et al. Essential Role of Interleukin-12/23p40 in the Development of Graft-Versus-Host Disease in Mice. Biol Blood Marrow Transplant (2015) 21(7):1195-204. doi: 10.1016/ j.bbmt.2015.03.016

37. Zeng D, Lewis D, Dejbakhsh-Jones S, Lan F, García-Ojeda M, Sibley R, et al. Bone Marrow NK1.1(-) and NK1.1(+) T Cells Reciprocally Regulate Acute Graft Versus Host Disease. J Exp Med (1999) 189(7):1073-81. doi: 10.1084/ jem.189.7.1073

38. Pillai AB, George TI, Dutt S, Teo P, Strober S. Host NKT Cells can Prevent Graft-Versus-Host Disease and Permit Graft Antitumor Activity After Bone Marrow Transplantation. J Immunol (2007) 178(10):6242-51. doi: 10.4049/ jimmunol.178.10.6242

39. Lan F, Zeng D, Higuchi M, Huie P, Higgins JP, Strober S, et al. Predominance of NK1.1+TCR Alpha Beta+ or DX5+TCR Alpha Beta+ T Cells in Mice Conditioned With Fractionated Lymphoid Irradiation Protects Against Graft-Versus-Host Disease: "Natural Suppressor" Cells. J Immunol (2001) 167(4):2087-96. doi: 10.4049/jimmunol.167.4.2087

40. Lowsky R, Strober S. Combined Kidney and Hematopoeitic Cell Transplantation to Induce Mixed Chimerism and Tolerance. Bone Marrow Transplant (2019) 54(Suppl 2):793-7. doi: 10.1038/s41409-0190603-4

41. Lowsky R, Takahashi T, Liu YP, Dejbakhsh-Jones S, Grumet FC, Shizuru JA, et al. Protective Conditioning for Acute Graft-Versus-Host Disease. N Engl J Med (2005) 353(13):1321-31. doi: 10.1056/NEJMoa050642

42. Anderson BE, McNiff J, Yan J, Doyle H, Mamula M, Shlomchik MJ, et al. Memory CD4+ T Cells do Not Induce Graft-Versus-Host Disease. J Clin Invest (2003) 112(1):101-8. doi: 10.1172/JCI17601

43. Zhang P, Wu J, Deoliveira D, Chao D, Chen BJ. Allospecific CD4(+) Effector Memory T Cells do Not Induce Graft-Versus-Host Disease in Mice. Biol Blood Marrow Transplant (2012) 18(10):1488-99. doi: 10.1016/ j.bbmt.2012.07.009

44. Bleakley M, Heimfeld S, Loeb KR, Jones LA, Chaney C, Seropian S, et al. Outcomes of Acute Leukemia Patients Transplanted With Naive T CellDepleted Stem Cell Grafts. J Clin Invest (2015) 125(7):2677-89. doi: 10.1172/ JCI81229

45. Korngold R, Friedman TM. Murine Models of Graft-Versus-Host Disease and Graft-Versus-Tumor Effect. Thomas' Hematopoietic Cell Transplant Fourth Edition (2009) 176-87. doi: 10.1002/9781444303537.ch14

46. Wu T, Young JS, Johnston H, Ni X, Deng R, Racine J, et al. Thymic Damage, Impaired Negative Selection, and Development of Chronic Graft-VersusHost Disease Caused by Donor CD4+ and CD8+ T Cells. J Immunol (2013) 191(1):488-99. doi: 10.4049/jimmunol.1300657

47. Kong X, Zeng D, Wu X, Wang B, Yang S, Song Q, et al. Tissue-Resident PSGL1loCD4+ T Cells Promote B Cell Differentiation and Chronic GraftVersus-Host Disease-Associated Autoimmunity. J Clin Invest (2021) 131(1): e135468. doi: 10.1172/JCI135468 
48. Panoskaltsis-Mortari A, Tram KV, Price AP, Wendt CH, Blazar BR. A New Murine Model for Bronchiolitis Obliterans Post-Bone Marrow Transplant. Am J Respir Crit Care Med (2007) 176(7):713-23. doi: 10.1164/rccm.200702$335 \mathrm{OC}$

49. Paz K, Flynn R, Du J, Qi J, Luznik L, Maillard I, et al. Small-Molecule BCL6 Inhibitor Effectively Treats Mice With Nonsclerodermatous Chronic GraftVersus-Host Disease. Blood (2019) 133(1):94-9. doi: 10.1182/blood-201803-839993

50. Deng R, Hurtz C, Song Q, Yue C, Xiao G, Yu H, et al. Extrafollicular CD4(+) T-B Interactions are Sufficient for Inducing Autoimmune-Like Chronic Graft-Versus-Host Disease. Nat Commun (2017) 8(1):978. doi: 10.1038/ s41467-017-00880-2

51. Hamilton BL, Parkman R. Acute and Chronic Graft-Versus-Host Disease Induced by Minor Histocompatibility Antigens in Mice. Transplantation (1983) 36(2):150-5. doi: 10.1097/00007890-198308000-00008

52. DeClerck Y, Draper V, Parkman R. Clonal Analysis of Murine Graft-vs-Host Disease. II. Leukokines That Stimulate Fibroblast Proliferation and Collagen Synthesis in Graft-vs. Host Disease. J Immunol (1986) 136(10):3549-52.

53. Zhang C, Todorov I, Zhang Z, Liu Y, Kandeel F, Forman S, et al. Donor CD4 $+\mathrm{T}$ and B Cells in Transplants Induce Chronic Graft-Versus-Host Disease With Autoimmune Manifestations. Blood (2006) 107(7):2993-3001. doi: 10.1182/blood-2005-09-3623

54. Zhao D, Young JS, Chen YH, Shen E, Yi T, Todorov I, et al. Alloimmune Response Results in Expansion of Autoreactive Donor CD4+ T Cells in Transplants That can Mediate Chronic Graft-Versus-Host Disease. J Immunol (2011) 186(2):856-68. doi: 10.4049/jimmunol.1002195

55. Eyrich M, Burger G, Marquardt K, Budach W, Schilbach K, Niethammer D, et al. Sequential Expression of Adhesion and Costimulatory Molecules in Graft-Versus-Host Disease Target Organs After Murine Bone Marrow Transplantation Across Minor Histocompatibility Antigen Barriers. Biol Blood Marrow Transplant (2005) 11(5):371-82. doi: 10.1016/ j.bbmt.2005.02.002

56. Zhang Y, Joe G, Hexner E, Zhu J, Emerson SG. Alloreactive Memory T Cells are Responsible for the Persistence of Graft-Versus-Host Disease. J Immunol (2005) 174(5):3051-8. doi: 10.4049/jimmunol.174.5.3051

57. Anderson MS, Venanzi ES, Klein L, Chen Z, Berzins SP, Turley SJ, et al. Projection of an Immunological Self Shadow Within the Thymus by the Aire Protein. Science (2002) 298(5597):1395-401. doi: 10.1126/science.1075958

58. Takaba H, Morishita Y, Tomofuji Y, Danks L, Nitta T, Komatsu N, et al. Fezf2 Orchestrates a Thymic Program of Self-Antigen Expression for Immune Tolerance. Cell (2015) 163(4):975-87. doi: 10.1016/ j.cell.2015.10.013

59. Takaba H, Takayanagi $\mathrm{H}$. The Mechanisms of $\mathrm{T}$ Cell Selection in the Thymus. Trends Immunol (2017) 38(11):805-16. doi: 10.1016/ j.it.2017.07.010

60. Herbin O, Bonito AJ, Jeong S, Weinstein EG, Rahman AH, Xiong H, et al. Medullary Thymic Epithelial Cells and CD8alpha(+) Dendritic Cells Coordinately Regulate Central Tolerance But CD8alpha(+) Cells are Dispensable for Thymic Regulatory T Cell Production. J Autoimmun (2016) 75:141-9. doi: 10.1016/j.jaut.2016.08.002

61. Hadeiba H, Lahl K, Edalati A, Oderup C, Habtezion A, Pachynski R, et al. Plasmacytoid Dendritic Cells Transport Peripheral Antigens to the Thymus to Promote Central Tolerance. Immunity (2012) 36(3):438-50. doi: 10.1016/ j.immuni.2012.01.017

62. Baba T, Nakamoto Y, Mukaida N. Crucial Contribution of Thymic Sirp Alpha+ Conventional Dendritic Cells to Central Tolerance Against BloodBorne Antigens in a CCR2-Dependent Manner. J Immunol (2009) 183 (5):3053-63. doi: 10.4049/jimmunol.0900438

63. Leventhal DS, Gilmore DC, Berger JM, Nishi S, Lee V, Malchow S, et al. Dendritic Cells Coordinate the Development and Homeostasis of OrganSpecific Regulatory T Cells. Immunity (2016) 44(4):847-59. doi: 10.1016/ j.immuni.2016.01.025

64. Yu W, Jiang N, Ebert PJ, Kidd BA, Müller S, Lund PJ, et al. Clonal Deletion Prunes But Does Not Eliminate Self-Specific Alphabeta CD8(+) T Lymphocytes. Immunity (2015) 42(5):929-41. doi: 10.1016/ j.immuni.2015.05.001

65. Zeng D, Strober S. Mechanisms of Tolerance. Thomas' Hematopoietic Cell Transplant Fifth Edition (2015) 136-49. doi: 10.1002/9781118416426.ch12
66. Felix NJ, Donermeyer DL, Horvath S, Walters JJ, Gross ML, Suri A, et al. Alloreactive T Cells Respond Specifically to Multiple Distinct Peptide-MHC Complexes. Nat Immunol (2007) 8(4):388-97. doi: 10.1038/ni1446

67. Young JS, Wu T, Chen Y, Zhao D, Liu H, Yi T, et al. Donor B Cells in Transplants Augment Clonal Expansion and Survival of Pathogenic CD4+ T Cells That Mediate Autoimmune-Like Chronic Graft-Versus-Host Disease. J Immunol (2012) 189(1):222-33. doi: 10.4049/jimmunol.1200677

68. Dudakov JA, Hanash AM, Jenq RR, Young LF, Ghosh A, Singer NV, et al. Interleukin-22 Drives Endogenous Thymic Regeneration in Mice. Science (2012) 336(6077):91-5. doi: 10.1126/science.1218004

69. Ni X, Song Q, Cassady K, Deng R, Jin H, Zhang M, et al. PD-L1 Interacts With CD80 to Regulate Graft-Versus-Leukemia Activity of Donor CD8+ T Cells. J Clin Invest (2017) 127(5):1960-77. doi: 10.1172/JCI91138

70. Sykes M. Mixed Chimerism and Transplant Tolerance. Immunity (2001) 14 (4):417-24. doi: 10.1016/S1074-7613(01)00122-4

71. Liu Y, Wang X, Zhu Y, Zhang M, Nasri U, Sun SS, et al. Haploidentical Mixed Chimerism Cures Autoimmunity in Established Type 1 Diabetic Mice. J Clin Invest (2020) 130(12):6457-76. doi: 10.1172/JCI131799

72. Teshima T, Reddy P, Liu C, Williams D, Cooke KR, Ferrara JLM, et al. Impaired Thymic Negative Selection Causes Autoimmune Graft-VersusHost Disease. Blood (2003) 102(2):429-35. doi: 10.1182/blood-2003-01-0266

73. Jin H, Ni X, Deng R, Song Q, Young J, Cassady K, et al. Antibodies From Donor B Cells Perpetuate Cutaneous Chronic Graft-Versus-Host Disease in Mice. Blood (2016) 127(18):2249-60. doi: 10.1182/blood-2015-09-668145

74. Forcade E, Kim HT, Cutler C, Wang K, Alho AC, Nikiforow S, et al. Circulating T Follicular Helper Cells With Increased Function During Chronic Graft-Versus-Host Disease. Blood (2016) 127(20):2489-97. doi 10.1182/blood-2015-12-688895

75. Flynn R, Du J, Veenstra RG, Reichenbach DK, Panoskaltsis-Mortari A, Taylor PA, et al. Increased T Follicular Helper Cells and Germinal Center B Cells are Required for cGVHD and Bronchiolitis Obliterans. Blood (2014) 123(25):3988-98. doi: 10.1182/blood-2014-03-562231

76. Rozans MK, Smith BR, Burakoff SJ, Miller RA. Long-Lasting Deficit of Functional T Cell Precursors in Human Bone Marrow Transplant Recipients Revealed by Limiting Dilution Methods. J Immunol (1986) 136(11):4040-8.

77. Dulude G, Roy DC, Perreault C. The Effect of Graft-Versus-Host Disease on T Cell Production and Homeostasis. J Exp Med (1999) 189(8):1329-42. doi: 10.1084/jem.189.8.1329

78. Sarantopoulos S, Ritz J. Aberrant B-Cell Homeostasis in Chronic GVHD Blood (2015) 125(11):1703-7. doi: 10.1182/blood-2014-12-567834

79. Matsuoka K, Kim HT, McDonough S, Bascug G, Warshauer B, Koreth J, et al. Altered Regulatory T Cell Homeostasis in Patients With CD4+ Lymphopenia Following Allogeneic Hematopoietic Stem Cell Transplantation. J Clin Invest (2010) 120(5):1479-93. doi: 10.1172/JCI41072

80. Suzuki I, Milner EC, Glas AM, Hufnagle WO, Rao SP, Pfister L, et al. Immunoglobulin Heavy Chain Variable Region Gene Usage in Bone Marrow Transplant Recipients: Lack of Somatic Mutation Indicates a Maturational Arrest. Blood (1996) 87(5):1873-80. doi: 10.1182/ blood.V87.5.1873.1873

81. Glas AM, van Montfort EH, Storek J, Green E-GN, Drissen RPM, Bechtold VJ, et al. B-Cell-Autonomous Somatic Mutation Deficit Following Bone Marrow Transplant. Blood (2000) 96(3):1064-9. doi: 10.1182/ blood.V96.3.1064

82. Jacob J, Kelsoe G, Rajewsky K, Weiss U. Intraclonal Generation of Antibody Mutants in Germinal Centres. Nature (1991) 354(6352):389-92. doi: $10.1038 / 354389 \mathrm{a} 0$

83. Berek C, Berger A, Apel M. Maturation of the Immune Response in Germinal Centers. Cell (1991) 67(6):1121-9. doi: 10.1016/0092-8674(91) 90289-B

84. Crotty S. T Follicular Helper Cell Differentiation, Function, and Roles in Disease. Immunity (2014) 41(4):529-42. doi: 10.1016/j.immuni.2014.10.004

85. Somers WS, Tang J, Shaw GD, Camphausen RT. Insights Into the Molecular Basis of Leukocyte Tethering and Rolling Revealed by Structures of P- and ESelectin Bound to SLe(X) and PSGL-1. Cell (2000) 103(3):467-79. doi: 10.1016/S0092-8674(00)00138-0

86. Johnston RJ, Su LJ, Pinckney J, Critton D, Boyer E, Krishnakumar A, et al. VISTA is an Acidic pH-Selective Ligand for PSGL-1. Nature (2019) 574 (7779):565-70. doi: 10.1038/s41586-019-1674-5 
87. Odegard JM, Marks BR, DiPlacido LD, Poholek AC, Kono DH, Dong C, et al. ICOS-Dependent Extrafollicular Helper T Cells Elicit IgG Production via IL-21 in Systemic Autoimmunity. J Exp Med (2008) 205(12):2873-86. doi: $10.1084 /$ jem. 20080840

88. Seth A, Craft J. Spatial and Functional Heterogeneity of Follicular Helper T Cells in Autoimmunity. Curr Opin Immunol (2019) 61:1-9. doi: 10.1016/ j.coi.2019.06.005

89. Zundler S, Becker E, Spocinska M, Slawik M, Parga-Vidal L, Stark R, et al. Hobit- and Blimp-1-Driven CD4(+) Tissue-Resident Memory T Cells Control Chronic Intestinal Inflammation. Nat Immunol (2019) 20(3):288300. doi: 10.1038/s41590-018-0298-5

90. Baroni SS, Santillo M, Bevilacqua F, Luchetti M, Spadoni T, Mancini M, et al. Stimulatory Autoantibodies to the PDGF Receptor in Systemic Sclerosis. N Engl J Med (2006) 354(25):2667-76. doi: 10.1056/NEJMoa052955

91. Alexander KA, Flynn R, Lineburg KE, Kuns RD, Teal BE, Olver SD, et al. CSF1-Dependant Donor-Derived Macrophages Mediate Chronic Graft-VersusHost Disease. J Clin Invest (2014) 124(10):4266-80. doi: 10.1172/JCI75935

92. Zorn E, Kim HT, Lee SJ, Floyd BH, Litsa D, Arumugarajah S, et al. Reduced Frequency of FOXP3+ CD4+CD25+ Regulatory T Cells in Patients With Chronic Graft-Versus-Host Disease. Blood (2005) 106(8):2903-11. doi: 10.1182/blood-2005-03-1257

93. Matsuoka K, Koreth J, Kim HT, Bascug G, McDonough S, Kawano Y, et al. Low-Dose Interleukin-2 Therapy Restores Regulatory T Cell Homeostasis in Patients With Chronic Graft-Versus-Host Disease. Sci Transl Med (2013) 5 (179):179ra143. doi: 10.1126/scitranslmed.3005265

94. Hirakawa M, Matos TR, Liu H, Koreth J, Kim HT, Paul NE, et al. Low-Dose IL-2 Selectively Activates Subsets of CD4(+) Tregs and NK Cells. JCI Insight (2016) 1(18):e89278. doi: 10.1172/jci.insight.89278

95. Whangbo JS, Kim HT, Nikiforow S, Koreth J, Alho AC, Falahee B, et al. Functional Analysis of Clinical Response to Low-Dose IL-2 in Patients With Refractory Chronic Graft-Versus-Host Disease. Blood Adv (2019) 3(7):98494. doi: 10.1182/bloodadvances.2018027474

96. Yi T, Li X, Yao S, Wang L, Chen Y, Zhao D, et al. Host APCs Augment In Vivo Expansion of Donor Natural Regulatory T Cells via B7H1/B7.1 in Allogeneic Recipients. J Immunol (2011) 186(5):2739-49. doi: 10.4049/ jimmunol.1002939

97. Zhao D, Zhang C, Yi T, Lin C-L, Todorov I, Kandeel F, et al. In VivoActivated CD103+CD4+ Regulatory T Cells Ameliorate Ongoing Chronic Graft-Versus-Host Disease. Blood (2008) 112(5):2129-38. doi: 10.1182/ blood-2008-02-140277

98. Leveque-El Mouttie L, Koyama M, Le Texier L, Markey KA, Cheong M, Kuns RD, et al. Corruption of Dendritic Cell Antigen Presentation During Acute GVHD Leads to Regulatory T-Cell Failure and Chronic GVHD. Blood (2016) 128(6):794-804. doi: 10.1182/blood-2015-11-680876
99. Koyama M, Hill GR. Alloantigen Presentation and Graft-Versus-Host Disease: Fuel for the Fire. Blood (2016) 127(24):2963-70. doi: 10.1182/ blood-2016-02-697250

100. Wu L, Li N, Zhang M, Xue S-L, Cassady K, Lin Q, et al. MHC-Mismatched Mixed Chimerism Augments Thymic Regulatory T-Cell Production and Prevents Relapse of EAE in Mice. Proc Natl Acad Sci USA (2015) 112(52):15994-9. doi: 10.1073/pnas.1521157112

101. Zhang M, Racine JJ, Lin Q, Liu Y, Tang S, Qin Q, et al. MHC-Mismatched Mixed Chimerism Restores Peripheral Tolerance of Noncross-Reactive Autoreactive T Cells in NOD Mice. Proc Natl Acad Sci USA (2018) 115 (10):E2329-37. doi: 10.1073/pnas.1720169115

102. Lu Y, Giver CR, Sharma A, Li JM, Darlak KA, Darlak LM, et al. IFNGamma and Indoleamine 2,3-Dioxygenase Signaling Between Donor Dendritic Cells and T Cells Regulates Graft Versus Host and Graft Versus Leukemia Activity. Blood (2012) 119(4):1075-85. doi: 10.1182/blood2010-12-322891

103. Amarnath S, Costanzo CM, Mariotti J, Ullman JL, Telford WG, Kapoor V, et al. Regulatory T Cells and Human Myeloid Dendritic Cells Promote Tolerance via Programmed Death Ligand-1. PloS Biol (2010) 8(2):e1000302. doi: 10.1371/journal.pbio.1000302

104. Amarnath S, Mangus CW, Wang JC, Wei F, He A, Kapoor V, et al. The PDL1-PD1 Axis Converts Human TH1 Cells Into Regulatory T Cells. Sci Transl Med (2011) 3(111):111ra120. doi: 10.1126/scitranslmed.3003130

105. Tian Y, Meng L, Wang Y, Li B, Yu H, Zhou Y, et al. Graft-Versus-Host Disease Depletes Plasmacytoid Dendritic Cell Progenitors to Impair Tolerance Induction. J Clin Invest (2021) 131(1):e136774. doi: 10.1172/ JCI136774

Conflict of Interest: The authors declare that the research was conducted in the absence of any commercial or financial relationships that could be construed as a potential conflict of interest.

Publisher's Note: All claims expressed in this article are solely those of the authors and do not necessarily represent those of their affiliated organizations, or those of the publisher, the editors and the reviewers. Any product that may be evaluated in this article, or claim that may be made by its manufacturer, is not guaranteed or endorsed by the publisher.

Copyright (c) 2021 Song, Kong, Martin and Zeng. This is an open-access article distributed under the terms of the Creative Commons Attribution License (CC BY). The use, distribution or reproduction in other forums is permitted, provided the original author(s) and the copyright owner(s) are credited and that the original publication in this journal is cited, in accordance with accepted academic practice. No use, distribution or reproduction is permitted which does not comply with these terms. 